Bangladesh J. Zool. 49(1): 181-185, 2021

- Scientific note

ISSN: 0304-9027

eISSN: $2408-8455$

\title{
FORAGING PARTICIPATION WITHIN A PAIR OF WHITE-BROWED WAGTAIL MOTACILLA MADERASPATENSIS GMELIN, 1789 FROM DHAKA CITY
}

\author{
Md. Fazle Rabbe* and Fahmida Tasnim Liza \\ Department of Zoology, University of Dhaka, Dhaka 1000, Bangladesh
}

Monogamous pair-bonding are seen in avian mating system improving the high-degree of synchronization and efficient breeding that results in successful reproduction (Emlen and Oring 1977, Klug 2018). To maximize the breeding success, the pairs often use multiple niches and adopt a variety of strategies (Alves et al. 2013). Intraspecific niche variation has been found to lower the overlapping of individuals and competition for food in birds like Coal Tit Parus ater, King Cormorant Phalacrocorax albiventer, etc. (Bolnick et al. 2003). But it still waits to be researched about prioritizing the effort of Whitebrowed Wagtail pair in similar foraging habitat.

White-browed Wagtail Motacilla maderaspatensis is usually seen in pairs all-round the year (Ali 1941), making an ideal group to investigate sex-specific variation in foraging. It is a sexually dimorphic, socially monogamous bird that breeds from March to October and, can be seen in riverbank as well as adjacent to urban settlements (Ali 1941, Rasmussen and Anderton 2005). Previous studies reported that depending on food availability and alteration of food supply, wagtails (e.g. White Wagtail Motacilla alba, Pied Wagtail M. albayarrellii, Black-backed Wagtail M. lugens) change their foraging grounds frequently i.e. they use habitats temporarily (Badyaev et al. 1996).

Being an adaptive bird, White-browed Wagtail can use urban water patches as food sources, and roosting sites (Ali 1941, Praveen 1993), but how these patches are used by breeding pair in terms of activity time for foraging is still unknown. In this study, we investigate the relative effort of male and female White-browed Wagtail in a plot situated in Dhaka city, Bangladesh.

The study area is an ongoing construction site $\left(23^{\circ} 52^{\prime} 12.12^{\prime \prime} \mathrm{N}, 90^{\circ} 24^{\prime}\right.$ 34.01"E) situated in Dakshinkhan, Dhaka (Fig.1). The construction work was halted at the beginning of April 2020 because of the COVID-19 crisis and due to heavy rainfall a temporary water body was formed. Before collecting data, we primarily observed White-browed Wagtail pair for four consecutive days (from 04 May to 07 May) to verify whether the same pair was visiting the plot or not. We

*Author for correspondence: <fazlerabbedu@gmail.com>

(C2021 Zoological Society of Bangladesh DOI: https://doi.org/10.3329/bjz.v49i1.53694 
noticed their morphological characteristics such as colour and size; monitored their visiting route to the plot, and determined their most active period. Later we became sure that it was the same pair of wagtail based on photographs, route, and activity pattern. The male and female wagtails were differentiated based on their external morphology and coloration.

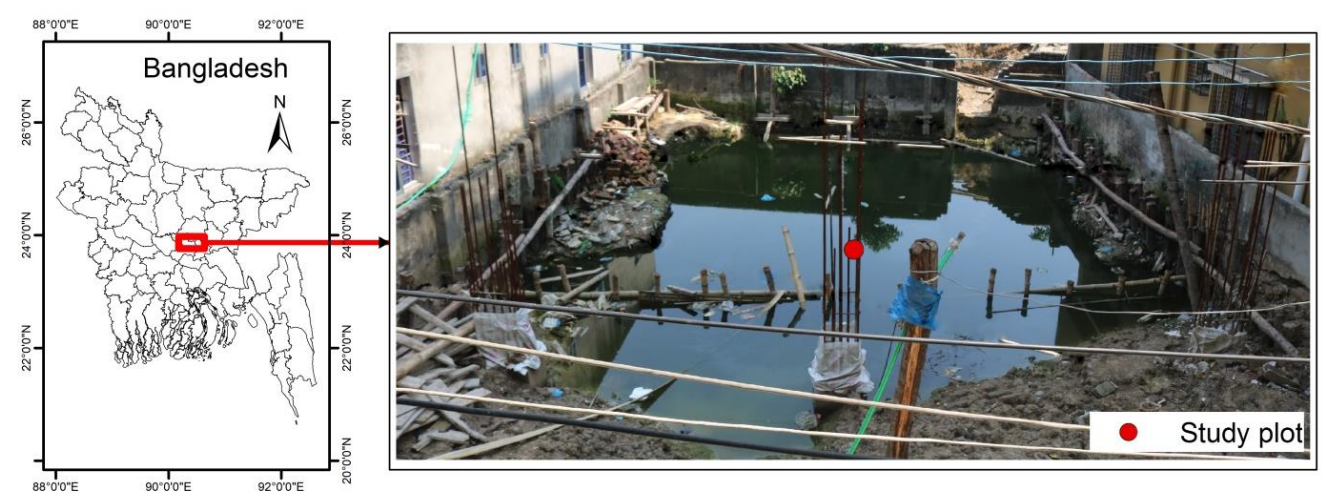

Fig. 1. Location of the study plot in Dhaka city

We collected data following the procedures given below-

- employed Focal Animal Sampling method (Altmann 1974) and repeated observations

- collected data for eight consecutive days (from 08 May to 15 May 2020) and spent ten hours (07.00 - $05.00 \mathrm{~h})$ per day

- traced both individuals' foraging performance and recorded the time spent using a digital stopwatch (KK-5898). By foraging performance, we mean all types of activity (e.g. scratching, scanning, probing, pecking) of the individuals during the stay at the study plot.

- one of the authors observed the first individual visited and traced it (whether it was male or female), while the other author waited for the second individual for observation to avoid the data jumbling

- videotaped the activity pattern in camera (Canon 760D) and later crosschecked their foraging time carefully with field data

- counted the frequency of both individuals visiting per day during the study period $(n)$ and calculated mean $(X)$ and standard error $(S E)$

- statistical analysis was done in $\mathrm{R}$ (version 3.6.1) and the significance level was set to $5 \%$

The ranges of activity time were $2-445$ seconds $(\overline{X \pm S E}=161.324 \pm 20.576$; $n=37)$ and $19-334$ seconds $(X \pm S E=156.222 \pm 22.074 ; n=18)$ for male and female respectively. Female spent less than half the time compared to male (about 47\%) in the study plot (Fig. 2a). Based on total activity time in a day, male and female 
wagtails differed significantly in foraging $(t=3.432 ; p=0.011)$. The relationship between frequency of visiting and foraging time by male was positively correlated but not significant $(r=0.431 ; p=0.242)$, whereas the correlation found for female was significant ( $r=0.697 ; p=0.05$ ). The activity time and frequency of visiting the plot for the male and female decrease gradually (Table 1).

The total time spent per day by male wagtail differed significantly $(F=3.247 ; p=0.011)$, and Kruskal Wallis test also revealed the same result $\left(x^{2}=18.19 ; p=0.011\right)$. The female wagtail also showed significant difference in activity time per day $\left(F=4.35 ; p=0.018\right.$ and $\left.x^{2}=13.947 ; p=0.052\right)$.

Table 1. Day wise activity time $(T)$, mean $(X)$, standard error $(S E)$, visiting frequency $(n)$ of male \& female wagtail

\begin{tabular}{|c|c|c|c|c|c|c|c|c|c|}
\hline \multicolumn{2}{|c|}{ Parameter/Day } & Day 1 & Day 2 & Day 3 & Day 4 & Day 5 & Day 6 & Day 7 & Day 8 \\
\hline \multirow{4}{*}{$\sum_{i}^{\frac{0}{\pi}}$} & $\mathrm{T}$ (second) & 913 & 850 & 1212 & 404 & 777 & 795 & 491 & 527 \\
\hline & $\bar{X}$ & 65.21 & 212.50 & 202.00 & 134.67 & 259.00 & 265.00 & 245.50 & 263.50 \\
\hline & $S E$ & 19.36 & 44.15 & 45.16 & 42.21 & 80.09 & 87.50 & 34.50 & 181.50 \\
\hline & $n$ & 14 & 4 & 6 & 3 & 3 & 3 & 2 & 2 \\
\hline \multirow{4}{*}{ 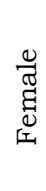 } & $\mathrm{T}$ (second) & 265 & 237 & 497 & 604 & 864 & 209 & 111 & 25 \\
\hline & $\bar{X}$ & 88.33 & 79.00 & 165.67 & 201.33 & 288.00 & 209.00 & 111.00 & 25.00 \\
\hline & $S E$ & 56.96 & 38.94 & 8.41 & 8.84 & 35.13 & 0.00 & 0.00 & 0.00 \\
\hline & $n$ & 3 & 3 & 3 & 3 & 3 & 1 & 1 & 1 \\
\hline
\end{tabular}

Pairing on the wintering ground is a type of feeding adaptation, which is seen in flocking species like White Wagtail (Zahavi 1971). Both male and female in a pair gain benefits in defending territory and searching for feeding ground. Usually in wagtail species, the male is the dominant partner who gets most of the food hence, it is on the female wagtail to find and recover any shortage of food by abandoning its territory (Zahavi 1971). In our study, we found that the female activity time (total $0.78 \mathrm{hrs}$.) was less than that of the male (total 1.73 hrs.) (Fig. 2a); which means the female might be busy defending its territory while the male spent more time in foraging. Gavrilov (1991) reported that the activity time of male White Wagtail in perching on vegetation and ground (3.5 hrs/day) was more than that of the females ( $2.64 \mathrm{hrs} /$ day), which supports our findings. The study also showed that male wagtail needs more energy in activities such as display flight, preening, night roosting etc. We assume that the male of this study also needed energy for other activities hence it was more active in foraging than that of the female. 

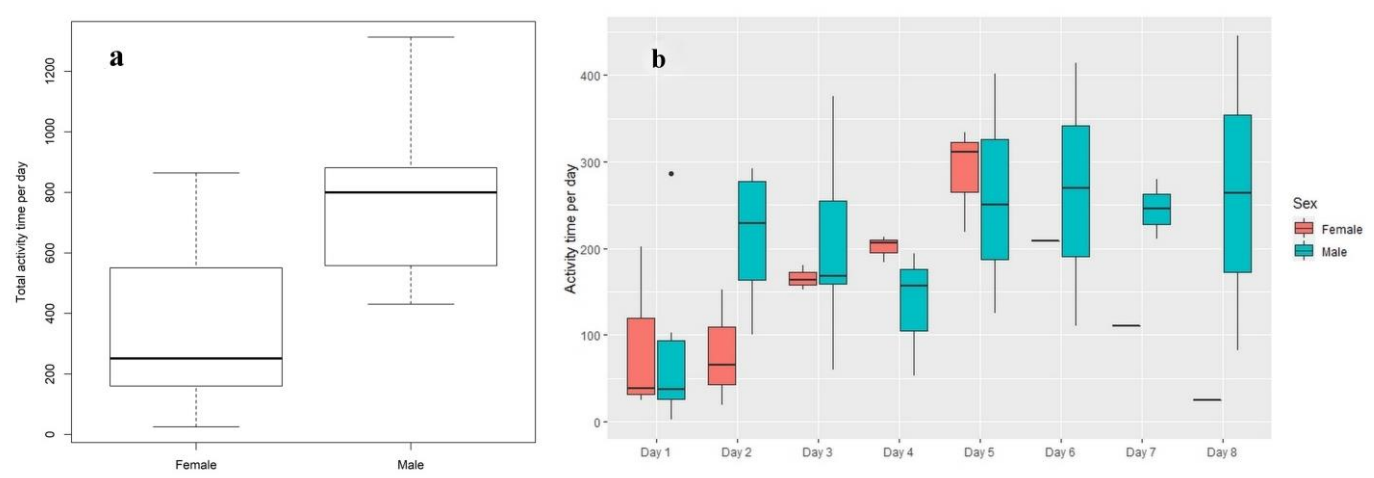

Fig. 2. (a) Total activity time of male and female White-browed Wagtail Motacilla maderaspatensis. (b) Variation in activity time of the male and female White-browed Wagtail in each day

Birds alter strategies to search prey in different habitats (Morrison et al. 1990). Different birds change their flocking behavior to territorial behavior for easy food catch and vice-versa (Kalela 1958, Zahavi 1971). Study of Zahavi (1971) suggested that wagtails may show flocking behavior or territorial behavior in different situations, where the determining factor is mainly food. In our study, we found that wagtails used the same habitat for a particular time but the frequency of visiting and spending time per day varied significantly (Fig. 2b). Usually, wagtails may approach each other in their feeding territories without aggression (Zahavi 1971). Moreover, we did not notice any aggression or conflict during foraging but sometimes they overlapped their foraging spots. In brief, our results show that the sexes of White-browed Wagtail invest unevenly during foraging.

Acknowledgements: We are grateful to the owners of the plot for letting us complete the work. We express our gratitude to the owner of the house from where the authors made field observation. We acknowledge the continuous support and encouragement of Professor Dr. M. Firoj Jaman and Mr. Md. Mahabub Alam. We thank Mr. Mahatub Khan Badhan, Mr. Md. Mokhlesur Rahman and Mahtima Tasnim Laz for their valuable comments and suggestions on the earlier version of the manuscript. Special thanks to A. F. M. Musannah Mahdi for his assistance during observation.

\section{LITERATURE CITED}

ALI, S. 1941. The Book of Indian Birds. Bombay Nat. Hist. Soc., 6, Apollo Street, Fort, Bombay.

ALTMANN, J. 1974. Observational study of behavior: sampling methods. Behaviour 49: 227-266. 
ALVES, J.A., GUNNARSSON, T.G., POTTS, P.M., SUTHERLAND, W.J. and GILL, J.A. 2013. Sex biases in distribution and resource use at different spatial scales in a migratory shorebird. Ecol. Evol. 3: 1079-1090.

BADYAEV, A.V., GIBSON, D.D. and KESSEL, B. 1996. White Wagtail (Motacilla alba) and Blackbacked Wagtail (Motacilla lugens). In: The birds of North America (Eds., Poole, A. and Gill, F.) Acad. Nat. Sci. Philadelphia, Pennsylvania, American Ornithol. Union, Washington, DC, pp.236-237.

BOLNICK, D.I., SVANBÄCK, R., FORDYCE, J.A., YANG, L.H., DAVIS, J.M., HULSEY, C.D. and FORISTER, M.L. 2003. The ecology of individuals: incidence and implications of individual specialization. Am. Nat. 161: 1-28.

EMLEN, S.T. and ORING, L.W. 1977. Ecology, sexual selection, and the evolution of mating systems. Science 197: 215-223.

GAVRILOV, V.V. 1991. Time and energy budget of a pair of White Wagtails (Motacila alba) during prenesting period. Ornithologia 25: 62-68.

KALELA, O. 1958. Überaußerbrutzeitliches Territorialverhaltenbei Vögeln. Ann. Acad. Sci. Fenn. Ser. Biol. 42: 142.

KLUG, H. 2018. Why monogamy? A review of potential ultimate drivers. Front. Ecol. Evol. 6: 30.

MORRISON, M.L., RALPH, C.J., VERNER, J. and JEHL Jr, J.R. 1990. Avian foraging: theory, methodology and applications. Los Angeles, CA: Cooper Ornithol. Society.

PRAVEEN, J. 1993. On the roosting of Large Pied Wagtails. Mal. Trog. 4: 30.

RASMUSSEN, P.C. and ANDERTON, J.C. 2005. Birds of south Asia: the Ripley guide. Smith. Instit. Lynx Eds., Washington, DC.

ZAHAVI, A. 1971. The social behaviour of the White Wagtail Motacilla alba alba wintering in Israel. Ibis 113: 203-211.

(Manuscript received on 10 October, 2020 revised on 2 December, 2020) 